\title{
HUMOR DAN KOMEDI DALAM SEBUAH KILAS BALIK SEJARAH SASTRA ARAB
}

\author{
Muhammad Yunus Anis \\ Jurusan Sastra Arab \\ Fakultas Sastra dan Seni Rupa \\ Universitas Sebelas Maret
}

\begin{abstract}
This paper describes the brief history of Humour in Arabs from (1) the earlier preIslamic period, (2) the Islamic period, (3) the medieval Arabic Literature (Abbasid), and (4) Mamaluke, Fatimid, Ayyubid, and Ottoman periods. This paper will try to show that Arabic literature is rife with the unique taste of Arabs in humour and comedy. Finally, the result of data analysis shows that humour in the earlier pre-Islamic period and the Islamic period is used dominantly at satirical poem which is called hija'. But in the medieval period until Ottoman period, Arabic humour and comedy has been spreading to the modern prose, shuch as romantic novel, elegant style of fable, public theater shadow play and some of elegiac short stories.

Keywords: humour, pre-Islamic period, Islamic period, Medieval, Abbasid, Mamaluke, Fatimid, Ayyubid, and Ottoman periods

$$
\begin{aligned}
& \text { ملخص } \\
& \text { يتناول هذا البحث الفكاهة أو المزاحة في تاريخ الأدب العرى مستخدما التحليل التاريخى. كانت الفكاهة }
\end{aligned}
$$

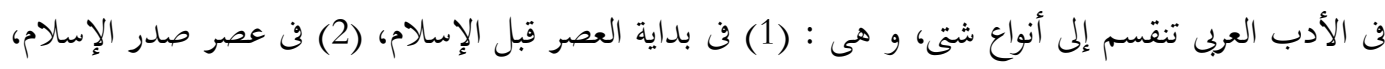

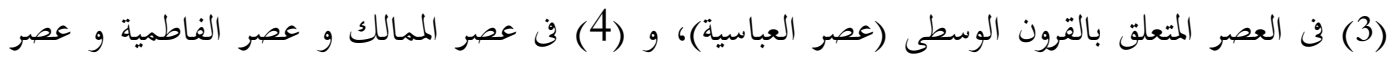

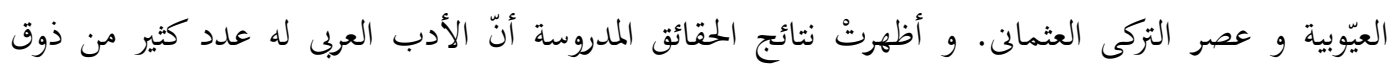

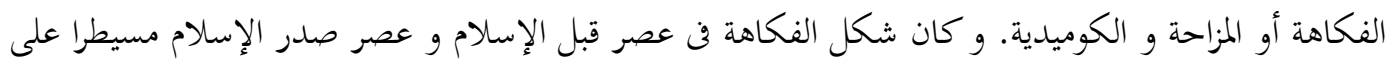

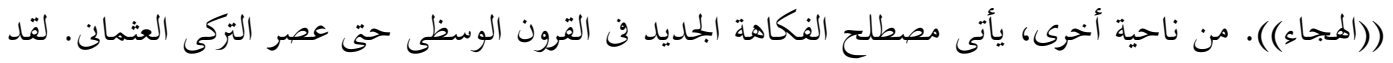

$$
\begin{aligned}
& \text { انتشرتْ الفكاهة في تلك العصور بالأشكال النثرية المتعددة مثل : الرواية الخيالية و الخرافة الحيوانية و المسرح } \\
& \text { الشعبى و دمية متحركة والرواية القصيرة. } \\
& \text { الكلمات الدليلية : الفكاهة, عصر قبل الإسلام, عصر صدر الإسلام, العصر العباسي, عصر الممالك, عصر } \\
& \text { التركى العثمانن }
\end{aligned}
$$

\section{Pendahuluan}

Di era globalisasi ini, manusia sering terjebak dalam iklim kejenuhan dan kebosanan. Berbagai macam aktifitas dan pekerjaan menyelimuti 24 jam waktu yang dimiliki manusia. Manusia modern dituntut dengan segudang aktifitas dan rutinitas yang menggurita. Tidak mengherankan jika pada sebuah titik tertentu manusia membutuhkan sebuah solusi cerdas untuk melepaskan kepenatan. Salah satu langkah untuk terlepas dari iklim tersebut, manusia berusaha untuk mencari hiburan yang bisa membawanya ke dalam keadaan yang 
lebih menyenangkan, rileks, dan segar. Hiburan sering didefinisikan sebagai sesuatu perbuatan yang menghibur hati dan melupakan kesedihan. Hiburan tersebut beraneka ragam. Ada yang berbentuk sebuah humor ataupun komedi.

Komedi adalah drama yang ditulis dengan gaya yang ringan, berseloroh, atau menyindir; khususnya lakon ringan yang sifatnya menghibur dan yang berakhir dengan bahagia, komedi disebut juga dengan drama ria (Zaidan, 1994:106). Setiap hari, para pemirsa televisi di Indonesia dipertontonkan dengan komedikomedi segar dan lawakan lucu, sebut saja komedi Opera Van Java (OVJ) yang ditayangkan rutin di saat para keluarga sedang menikmati waktu istirahat mereka di rumah. Lakon-lakon yang ditampilkan oleh para wayang OVJ selalu menghibur masyarakat dengan guyonan ringan khas kekinian dan kedisinian, walhasil guyonan OVJ lekat di hati pemirsa televisi.

Adapun Humor adalah kejenakaan yang menimbulkan kesenangan; kecakapan melihat, memakai, atau mengutarakan sesuatu yang menyenangkan, yang menimbulkan tertawa; terjadi terutama dari pengenalan dan pengutaraan keanehan, kemustahilan dalam suasana atau lakuan tertentu; tidak selamanya menimbulkan gelak meskipun selalu mampu mengatakan apa yang menyenangkan atau menggelikan. Poerwadarminta (1976:365) menambahkan bahwasannya humor merupakan kemampuan "merasai" sesuatu yang lucu atau yang menyenangkan, selain itu humor juga dapat diartikan sebagai keadaan dalam cerita yang menggelikan hati.

Istilah humor sendiri dalam bahasa Inggris sering disebut dengan humour (Zaidan, 1994:85-86). Adapun dalam bahasa Arab humor disebut dengan ladda'ābah/ (الدعابة) dan /al-fukāhah/ (الفكاهة) (Collin, 1988:262). Kedua kata tersebut, berdasarkan komponen maknanya, dekat sekali dengan kata 'sendagurau' yang dalam bahasa Arab disebut dengan /almuzāch/ (المزاح) atau /al-muzāchah/
(المزاحة) yang berarti joking, jesting, kidding, fun (making), dan pleasantry (Baalbaki, 1995:1025). Dalam bahasa Arab, humor sering disebut juga dengan istilah las-sukhriyyah/ (الئخريَّة), yang merupakan gabungan dari unsur satir (الهجاء) dan lawakan (الأعابة) (Rāghib, 1996:179).

Akhirnya, dari definisi humor di atas dapat disimpulkan bahwa humor setidaknya mengandung unsur tawa, senang dan menyenangkan, ejekan, sindiran, namun terkadang juga ada unsur keanehan. Di balik keanehan tersebut, sebuah humor justru menjadi media hiburan yang banyak dicari oleh manusiamanusia modern penggila kerja. Humor seakan menjadi obat mujarab kepenatan dan kejenuhan. Namun di satu sisi, jika kita mau menengok beberapa buku-buku berbahasa Arab, banyak sekali sebuah pesan agar kita menghindari bercanda (baca: humor). Karena dikhawatirkan humor atau bercanda yang berlebihan akan mengakibatkan hati keras, hilang wibawa, dan menjadi manusia yang tidak pernah serius.

Hal tersebut juga diamini oleh beberapa sastrawan modern Arab. Beberapa penulis Arab modern, seperti Muhammad Khalaf Ahmad dan orientalis modern seperti D.S. Margoliouth, menyatakan bahwa "tidak ada" humor dalam Sastra Arab Klasik (Mubeen, 2008:13). Di dalam kitab An-Nachwu AlWädich (sebuah kitab dasar untuk pembelajar tingkat awal gramatika bahasa Arab) disebutkan beberapa statemen yang melarang bercanda berikut.

$$
\text { المزاح مُضْرّ }
$$

(1) Al-mizāchu mudhirrun 'bercanda itu berbahaya'

(Al-Jārim, 1999:37)

$$
\text { لا تُكثر مِنَ الضَّحِكِ }
$$

(2) Là tuktsir minadh-dhachik

bercanda' 'janganlah memperbanyak 
(Al-Jārim, 1999:52)

$$
\text { لا تَتَعََّد كثرةً المزَّاح }
$$

(3) Là tata'awwad katsratalmizāchi bercanda'

'janganlah membiasakan

(Al-Jārim, 1999:54)

$$
\text { أترُكِ المزاحَ }
$$

(4) Utrukil-mizācha

'tinggalkanlah bercanda'

(Al-Jārim, 1999:56)

Dengan demikian humor menjadi sebuah problematika yang dilematis, ibarat buah simalakama, di satu sisi humor menjadi obat kejenuhan dan media hiburan, di sisi lain jika terlalu banyak bercanda juga tidak sehat. Stigma inilah yang akhirnya menyebabkan, humor dalam bahasa Arab jarang dikaji dan diteliti. Maka dari itu, penelitian perihal humor Arab menjadi penting. Khalayak perlu mengetahui bentuk humor dan komedi dalam Sastra Arab.

Selain dari problematika humor yang menempati posisi dilematis di atas, beberapa masalah yang merangsang pencarian penulis adalah apakah ada relevansi antara humor dan karya sastra dalam rentetan alur periode sejarah sastra Arab dan bagaimanakah bentuk humor tersebut. Maka dari itu, tulisan ini merupakan usaha untuk mengulas tuntas dengan ringkas masalah tersebut bersandarkan pada perspektif sejarah. Dari tulisan ini, diharapkan dapat memberikan pencerahan kepada khalayak pembaca perihal bagaimana sebuah humor Arab berkembang dari masa sebelum Islam menuju masa kelahiran Islam sampai pada masa kekaisaran Ottoman. Tulisan kilas balik ini secara jujur berusaha untuk memaparkan bahwasannya Sastra Arab sejatinya juga dipenuhi oleh iklim dan nuansa humor yang cukup tinggi.

\section{Pembahasan}

\subsection{Humor dan komedi dalam Sastra Arab (sejak masa kelahiran Islam sampai dengan Kekaisaran Ottoman)}

Tertawa/ menertawakan/ dan memperolok-olokan (mocking) sejatinya merupakan watak natural (natural disposition) dari manusia sosial. Manusia mana yang tidak pernah tertawa? Tidak ada manusia di muka bumi ini yang tidak pernah tertawa. Tertawa sejatinya menjadi unsur pembeda manusia sebagai hewan yang berakal dengan hewan-hewan lain di dunia ini. Mubeen (2008:13) menyimpulkan bahwa manusia secara alami merupakan hewan yang tertawa (laughing animal). Tertawa itu justru memanusiakan manusia. Dalam kilas balik Sejarah Sastra Arab, humor dan komedi ini dapat ditelisik dari beberapa periode berikut: (1) masa sebelum Islam, (2) masa Islam/ masa Rasulullah, (3) masa abad pertengahan (medieval) Sastra Arab, dan (4) masa dinasti Fatimiyyah, Ayubiyyah, Mamluk, dan Kekaisaran Ottoman.

\subsubsection{Masa Sebelum Islam (Pre-Islamic Period)}

Humor dalam Kesusastraan Arab sejatinya banyak mengalami efek penetrasi dari kebudayaan India, Persia, Cina, dan Yunani. Sejarah Sastra Arab awal sangat didominasi oleh genre puisi kuno (ancient poetry). Masyarakat Arab sangat mengagumi keindahan puisi. Puisi menjadi nafas dan gerak langkah kehidupan Bangsa Arab. Sehingga pada akhirnya, puisi menjadi gambaran kehidupan dan pemikiran masyarakat Arab pada waktu itu. Meskipun masyarakat Arab pada periode awal (jahiliyyah) terkenal dengan watak yang keras kepala, nomaden, dan hidup secara sederhana dan alami, mereka tetap mencintai humor dan ejekan.

Apabila kita mau menelisik dan menganalisis humor dan satir dalam literatur Sastra Arab Klasik dengan metodologi sejarah, maka kita akan menemukan ratusan referensi kesusastraan 
yang memiliki materi leksikon (kosa-kata) yang mendukung tema humor dan ejekan dalam sebuah karya sastra. Dalam cerita Yunani dan Romawi Kuno istilah "satir" pada awalnya merupakan makhluk berwujud setengah manusia, setengah binatang, yang konon kabarnya suka anggur dan wanita; selain itu satir juga berarti laki-laki yang tidak dapat mengendalikan nafsu birahinya. Adapun dalam dunia sastra, istilah Satir - Satire merupakan gaya bahasa yang dipakai dalam kesusastraan untuk menyatakan sindiran atau ejekan terhadap suatu keadaan atau seseorang (Sugono, 2008:1370). Isitah satire (lampoonery, defamatory poem) sendiri dalam bahasa Arab dikenal dengan istilah /hija '/l (هجاء) yang merupakan salah satu tujuan dari puisi kuno (Baalbaki, 1999:1202).

Humor pada akhirnya menjadi karakteristik paling menonjol dalam sebuah satir (tema genre puisi) pada masa itu. Para sastrawan menyangkal 'lawan sastra' mereka atau kabilah lain dengan menggunakan satire-satire yang penuh dengan unsur ejekan dan humor. Mereka saling menjatuhkan antar kabilah dengan memanfaatkan unsur-unsur kelemahan yang dimiliki oleh kabilah lain, seperti (1) cowardice - perasaan pengecut, (2) avarice - keserakahan/ketamakan, (3) cupidity - nafsu yang besar untuk berkuasa, (4) disloyalty - ketidaksetiaan, (5) betrayal - penghianatan, dan (6) treachery - penghianatan. Hal ini bisa kita lihat pada contoh hijā' berikut.

$$
\begin{aligned}
& \text { أبُوكَ قَتيلُ الجحوع قَيسُ بْنُ جَندَلِل }
\end{aligned}
$$

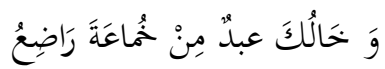

$$
\begin{aligned}
& \text { Abūka qati>lul-jū'i Qaisu ibnu }
\end{aligned}
$$
khumā'ata rādhi'u

'bapakmu mati karena kelaparan (korban kelaparan) Qais ibn Jandal dan Pamanmu hamba dari kabilah Khuma'ah yang rendahan (Wargadinata, 2008:98).
Satir di atas mengejek lawan bicaranya dengan menyebut ayah lawan bicara sebagai korban kelaparan dan pamannya sebagai kabilah rendahan.

\subsubsection{Masa Islam (Islamic Period)}

Pada era Rasulullah, orang-orang yang tidak mempercayai dakwahnya selalu membuat kekonyolan untuk mengusik dan menghentikan dakwah Nabi Muhammad SAW. Ibnu Hisyam menarasikan bahwa ketika seorang Irashi (warga asing di wilayah Makkah) meminta kelompok Quraisy untuk membantunya mengembalikan unta-untanya yang ditangkap, mereka (Quraisy) mengisyaratkan dengan cara humor yang menggunakan kata-kata yang diklaim milik Rasulullah: "pergilah pada nya! dia akan membantumu dalam mengembalikan untamu." Padahal Rasulullah sendiri tidak pernah menggunakan kata-kata itu. Dalam hal ini kita dapat membayangkan bahwa kelompok Quraisy pada waktu itu sambil tertawa-tawa mencoba merendahkan makna ujaran Rasulullah ketika Si-Irashi meminta bantuan dalam mengembalikan untanya.

Sebuah celaan dengan tertawaan dan ditambah dengan sebuah hasutan merupakan akhlaq yang tidak terpuji. Semua hal tersebut ditunjukkan oleh kelompok Quraisy pada perangai Rasulullah, terutama sekali bertujuan untuk menarik spirit putus asa yang memang ada dalam diri kelompok Quraisy. Sehingga, mereka membuat kelucuan dengan menyebut Rasulullah sebagai manusia biasa yang tidak normal (insane person). Mereka sering mengejek Rasulullah, dengan ujaran berikut.

"Wahai Muhammad, kepada siapa sejatinya Al-Qur'an itu diturunkan, sungguh kamu sebenarnya orang yang tidak normal" (Al-Hijr: ayat 6).

Untuk melawan ejekan-ejekan Quraisy tersebut, Al-Qur'an pun menggunakan ujaran-ujaran yang bersifat menyindir (satirical style). Al-Qur'an menggunakan kata istihzā' (استهزاء) dan 
sukhriyyah (سخرية) yang keduanya berarti ejekan. Dengan demikian Al-Qur'an membalas kelucuan orang-orang yang tidak mempercayai Rasulullah tersebut dengan ayat berikut.

"(Orang munafik) yaitu mereka yang mencela orang-orang beriman yang memberikan sedekah dengan sukarela dan yang (mencela) orang-orang yang hanya memperoleh (untuk disedehkankan) sekadar kesanggupannya, maka orangorang munafik itu menghina mereka. Allah akan membalas penghinaan mereka dan mereka akan mendapat azab yang pedih." (At-Taubah: ayat 79)

Al-Qur'an juga merespon ejekan/ istihz $\bar{a}^{\prime}$ mereka dengan ayat berikut.

"Allah akan memperolok-olokan mereka dan membiarkan mereka terombang-ambing dalam kesesatan." (AlBaqarah: ayat 15)

Al-Qur'an juga menyangkal para hipokrit dengan menggunakan kata /basysyiril (بشّر) yang berarti (berikan kabar baik). Kata tersebut digunakan tidak dengan makna sesungguhnya, tapi lebih pada makna ejekan kepada para hipokrit. Hal ini dapat dilihat pada ayat berikut.

"Kabarkanlah (basy-syiri) kepada orang-orang munafik bahwa mereka akan mendapat siksaan yang pedih" (An-Nisa' 138)

Pada ayat tersebut, apakah siksaan pedih merupakan kabar gembira. Padahal ayat tersebut dalam bahasa Arab menggunakan kata /basy-syiri/ yang berarti "berikanlah kabar baik!" Dalam hal ini, Al-Qur'an mencoba untuk melakukan ejekan dengan model bahasa satire kepada para hipokrit. Satire merupakan ungkapan yang formal dan panjang lebar tentang ketololan dan kejahatan untuk mentertawakan atau menolak sesuatu. Bentuk ini tak perlu bersifat ironis atau menyindir (Lubis, 1994:169).

Rasulullah dan para sahabatpun sering menggunakan lelucon (joke) dan ejekan (jesting) antara satu sama lain untuk membuat suasana menjadi menyenangkan. Salah satu sahabat Nabi bernama Nu'man merupakan sahabat yang terkenal dengan naluri humorisnya. Para ahli sejarah banyak yang mencatat model ejekan/jesting dari Nu'man. Alkisah, sebuah kafilah dagang datang ke kota Madinah dengan membawa peralatan sehari-hari untuk dijual. Nu'man membeli salah satu peralatan dari kafilah tersebut tanpa membayarnya. Kemudian ia menawarkannya ke Rasulullah. Ketika salah satu saudagar menagih harga barang tersebut, Nu'man bergegas pada Rasulullah bersama saudagar tersebut, lalu ia berkata: "Wahai Rasulullah, tolong bayarkan barang tersebut!" Rasulullah pun terkejut dengan hal itu. Ia kemudian berkata kepada Nu'man: "kamu belum memberikan barang itu kepadaku." Nu'man berkata: "aku tidak memiliki uang di kantongku, padahal aku ingin sekali Rasulullah memakai barang tersebut, maka dari itu aku membelikannya untukmu." Rasulullah pun tertawa mendengarnya, kemudian ia membayarkan barang tersebut untuk Nu'man.

Dikisahkan pula bahwa para sahabat dan umat muslim lainnya membalas ejekan orang-orang kafir dan kelompok badui dengan menggunakan humor-humor. Dinarasikan pula bahwa kelompok Badui mendatangi Rasulullah pada masa Badar, kemudian salah seorang dari mereka bertanya kepada Rasul: “jika kamu memang benar-benar Rasulullah, coba tunjukkan padaku apa yang ada di dalam rahim unta betinaku!" Salah seorang sahabat nabi bernama Salama menjawab pertanyaan tersebut dengan sedikit mengejek: " Baiklah! Saya akan mengatakan hal itu padamu, coba kamu loncat di atas unta betinamu itu, maka kamu akan menemukan 'anak domba' di dalam rahim unta betinamu itu." Namun Rasulullah tidak begitu suka dengan ejekan tersebut.

\subsubsection{Humor dan Komedi pada Masa Pertengahan Sastra Arab (Medieval Arabic Literature)}


Pada masa dinasti Abbasiyah, penetrasi dari budaya asing seperti India, Persia, dan Romawi, tampak jelas sekali mempengaruhi budaya nomaden Arab. Pengaruh dari budaya asing tersebut cukup luas dalam lingkaran sastra Arab, bahkan terkadang menghasilkan bias pada nuansa asli Sastra Arab secara umum. Pada masa pertengahan ini, tren baru mulai muncul dalam dunia sastra, hal ini dikarenakan banyak masyarakat sosial muslim mulai hidup dalam masa kemakmuran dan kemewahan. Dengan demikian secara natural, model humor dan ejekan (irony) pun mengalami babak baru yang berbeda dengan tabiat dan model humor pada masa nomaden (nomadic style).

Beberapa tokoh penulis dan penyair humoris Sastra Arab yang terkenal pada masa ini, seperti: Bashshar bin Burd, Abu Nawas, Hammad Ajrad, Abdul Samad, al'Atabi, Al-Hamdumi, Ibnu Al-Rumi, Ibnu Sakra. Abu Nawas sebagai icon humor dalam sastra Arab pada masa Dinasti Abbasiyah.

Adapun dalam genre prosa, penulisnya yang terkenal adalah Al-Jāhiz, Abu al-Aina, Badiul-Zaman al-Hamdani. Mereka menulis dan menghasilkan karya sastra hebat yang bernuansakan humor dan komedi. Dalam hal ini, prosa diartikan sebagai karya sastra yang tidak berbait-bait dan tidak bersajak. Novel, cerpen, dan roman ditulis dengan cara ini. Persenyawaan yang harmonis antara bentuk dan isi adalah syarat untuk prosa kesusastraan yang baik (Lubis, 1994:165). Terdapat kelompok lain dalam periode yang sering disebut dengan "penyair gila" (lunatic poets) yang tampak berkarya dengan cara mengkolaborasikan antara tertawaan (ridicule) dan ejekan (mockery) dengan sebuah sifat kegilaan (madness). Para penyair gila ini sering disebut dengan "al-Shu'ra al-majān" atau majnūn yang diartikan dengan kata "gila" dalam bahasa Arab.

Para figur terkenal dalam kelompok ini seperti: Abu Galāla al-Makhzumi, yang memiliki puisi elegi terhadap keledainya.
Elegi diartikan sebagai sebuah bentuk sajak pada zaman klasik Yunani dan Latin. Biasanya berupa keluhan dan ratapan yang ditujukan kepada seorang kekasih (dalam hal ini seekor keledai kesayangan). Dalam Sastra Eropa Barat pada umumnya kata elegi dipergunakan bagi setiap syair lirik yang merenungkan mengenai aspek-aspek tragis dalam hidup manusia, bertetapan dengan meninggalnya seorang kekasih atau peristiwa menyedihkan (Hartoko, 1986:37). Dalam periode ini, penyair lain yang terkenal dengan eleginya adalah $\mathrm{Abu}$ Hakima.

Humor dalam gaya bahasa periode ini lebih condong pada ketenangan jiwa, hati, dan pikiran, begitu pula dilengkapi dengan model alami atau natural yang dekat sekali dengan gaya bahasa (style) masyarakat dalam percakapan sehari-hari. Tradisi humor pada masa ini, secara fundamental dalam Sastra Arab digagas oleh al-Jāhiz (777-869), pada abad kedua Hijriyah. Hasil kesusasteraan yang terkenal dari al-Jāhiz tidak hanya seputar prosa kesusasteraan, namun ia juga menulis perihal teologi, retorika, filologi, dan bidang, yang dewasa ini sering disebut sebagai kritik sosial (social criticism).

Al-Jāhiz memiliki pandangan pembeda antara unsur seni yang natural (nature of art) dengan karya sastra (literature). Seiring dengan hal tersebut, Al-Jāhiz sering mengatakan bahwa "terkadang sesuatu yang dianggap sempurna oleh seseorang bukanlah sebuah kesempurnaan, dan sesuatu tersebut justru dianggap sebagai "hal keramat" yang hilang statusnya bersamaan dengan terbitnya matahari pada permulaan hari dan ia sejatinya adalah keseluruhan kehidupan itu sendiri." Unsur natural alam itu diperlihatkan oleh Al-Jāhiz dengan tidak mengagungkan sebuah kesempurnaan. Kesempurnaan yang paripurna itu adalah kehidupan itu sendiri.

Al-Jāhiz berhasil mengenalkan tren modern dalam Sastra Arab dan menemukan corak baru humor dan satire dalam genre prosa. Ia lebih banyak 
menggunakan metode tradisional. Ia terkenal sebagai seorang sastrawan yang saleh dan berbudi tinggi. Ia juga lebih fokus kepada para mitra tutur (mutakallimun) dan ia juga sangat tertarik dengan kontroversi-kontroversi yang ada pada masyarakat tutur. Dua buku yang terkenal dari Al-Jahiz, untuk melacak unsur humor dan komedi Arab, adalah Kitabul Bayan wal Tabyeen (Book of Eloquence and Exposition) dan Kitab alHayawan (Book of Animals). Ia merupakan penulis Arab pertama yang menulis perihal humor (joking) dan ejekan (jesting).

Nama al-Jāhiz juga banyak dirujuk oleh para sejarawan klasik dalam bukubuku berikut: Kitab al-Bukhala (Book of Misers: Buku perihal Si Kikir), Kitab AlNawadir (Book of Jokes), Kitab Nawadar al-Hasan (Book of Hasan's Jokes), Kitab al-Mulahi wa alturaf (Book of Funny Stories and Cosmic Anecdotes), Kitab ulmuzahik (Book of Laughing Stock), Kitab al muzah wa al jidd (Book of Humour and Fun). Salah satu kitab Al-Jāhiz yang paling terkenal perihal humor dan ejekan adalah Kitab al-Bukhala. Dalam buku ini, sebagai salah satu perintis humor Arab, ia menyampaikan cerita humor dan narasi komedi perihal ketamakan dan kekikiran. Selera humor Al-Jāhiz sederhana tapi jelas. Al-Jāhiz tidak hanya menampilkan unsur tawa sebagai hiburan, namun sebagai guyonan cerdas, ia mampu menghadirkan humor sebagai media untuk berfikir dan introspeksi.

Quote Al-Jāhiz yang paling terkenal adalah:

$$
\begin{aligned}
& \text { لا يغضب من المزاح إلا كزٌّ الحُلُقق و لا } \\
& \text { يرغب عن المفاكهة إلاّ ضيّقُ العَطَنَ }
\end{aligned}
$$

Lā yaghdhab minal-muzāchi illa kazzul-khuluq wa lā yarghab 'anilmufākahah illā dhayyiqul- 'athan

"tak ada seorangpun yang akan marah terhadap humor, kecuali hanya orang-orang yang berwatak kaku (rigid), dan tak ada seorang pun yang akan meninggalkan komedi kecuali hanya orang-orang yang berfikiran sempit".

Dalam hal ini, Al-Jāhiz memposisikan humor sebagai media distorsi kemarahan seseorang. Marah akan hilang dengan humor dan orang akan lebih berfikiran luas dengan menikmati komedi. Al-Jahiz sebagai humoris Arab abad pertengahan juga sering memunculkan slogan bahwa:

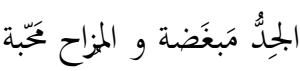

Al-jiddu mabghadhah walmuzāchu machabbah

"Keseriusan (keformalan) itu sejatinya dibenci oleh setiap orang dan humor selalu dicintai oleh setiap orang". Humor adalah lawan dari keformalan, kerigidan, kekakuan, dan keseriusan yang berlebihan.

Selain Al-Jāhiz, pelopor humor Arab pada periode ini adalah Ibnu al-Muqaffa.Ia berhasil mengkolaborasikan antara humor dan satir dalam sebuah tulisan yang terkesan cukup serius. Buku al-Muqaffa yang cukup terkenal sampai saat ini adalah fabel Kalila wa Dimna yang diterjemahkan dari bahasa Persia. Dalam cerita tersebut unsur humor yang berupa ankedot mulai masuk ke genre prosa.

\subsubsection{Humor pada Masa Dinasti Fatimiyyah, Mamalik, dan Ottoman}

Pada masa Ibnu Toulun, salah satu bintang puisi humor muncul, ia bernama Al-Jamal Al-Akbar. Dia berkoalisi dengan para pembesar raja. Namun di satu sisi ia juga menulis perihal candaan (jokes), cerita-cerita humor tentang kekikiran, pejabat yang selalu menjadi benalu bagi kehidupan dll. Selain itu, pada masa ini juga terdapat pakar puisi Arab lain, yang bernama al-Jamal al-Asgar. Ia memiliki daya tarik humor yang cukup tinggi.

Adapun penyair humoris (humorist poet) yang paling briliant dan paling terkemuka pada masa ini adalah Sebawae al-Misri. Sebagai seorang penyair humoris, Sebawae al-Misri selalu berpura-pura 
untuk menjadi orang bodoh, dungu, dan gila (lunatic) untuk mengkritisi aturanaturan penjajah asing dan para prajurit bayarannya. Secara cerdas, Ia juga memanfaatkan humor sebagai media untuk menjelaskan kebrutalan dan kekejaman penguasa pada masa itu. Sebawae al-Misri juga tidak menggunakan bahasa-bahasa yang aneh dan salah, begitu pula ia juga tidak pernah menggunakan bahasa-bahasa sindiran yang memalukan. Orang-orang sering berkumpul dengannya dalam sebuah "pasar tawa", dengan saling bercanda, mengejek, melawak satu sama lain.

Sebawae al-Misri juga sering menggunakan ayat-ayat al-Qur'an, Hadist Nabi, dan prosa berirama dalam humornya. Humor khasnya selalu muncul dari percampuran antara kata-kata dan maknamakna. Sehingga, hal tersebut justru menjadi manifestasi/ perwujudan dari triktrik ajaibnya (magical tricks). Dia tidak menggunakan maksud humor untuk membuat orang lain tertawa dan terhibur, namun ia selalu serius dan keras melawan rezim Ikhseed dan pemerintahannya. Suatu saat, dengan pidato nasehatnya, ia mengejutkan para pendengarnya dengan ungkapan berikut.

$$
\begin{aligned}
& \text { حَصَلتِ الدنيا على أقطعَ و أقرعَ و أرقعَ } \\
& \text { "hasalat ad-dunya ala aqta wa } \\
& \text { aqra wa arqa" } \\
& \text { 'dunia ini telah mengambil posisi } \\
& \text { aqta' (bisu), aqra' (gundul, kosong), dan } \\
& \text { arqa' (kebodohan). }
\end{aligned}
$$

Berlandaskan pada kata $\boldsymbol{a q t a}^{\prime}$ (kebisuan), Sebawae al-Misri mengkritik dengan humor ejekan pada kediktatoran Gubernur Baghdad pada waktu itu, yaitu Ibnu Buwai al-Dailmi. Dengan kata aqra' (gundul), dia mengkritik kediktatoran Gubernur Kota Halb pada masa itu, yaitu Saiful Dula al-Hamdani. Adapun kata arqa' (tak tau malu) digunakan oleh Sebawae al-Misr untuk mengkritik Pemimpin Mesir pada waktu itu, Kafur AlIkhseedi. Dia selalu memanggil pemimpin Mesir, al-Ikhseedi, sebagai "pria yang telah dikebiri". Kritikan pedas kepada pemerintahan itu sangat tajam dan lebih keras daripada apa yang telah dilakukan oleh Sastrawan Arab lain, yaitu AlMutanabbi. Kesadaran dan naluri politiknya yang telah dewasa membuatnya dapat menciptakan sebuah humor sederhana, bijaksana, dan tajam, begitu pula sebuah ejekan kritis. Apa yang telah dilakukan oleh Sebawae al-Misri ini, mengingatkan kita pada sosok Charlie Chaplin.

Sebagai artis, Chaplin menemukan suatu gaya penampilan individu yang khas, gabungan gaya badut sirkus dan pelawak dengan keindahan akrobatik, gerak yang ekspresif, kemampuan ekspresi muka, dan ketepatannya yang tanpa cela. "Gelandangan kecil" Chaplin, merupakan suatu simbol universal tentang kemenangan individualitas atas kesengsaraan dan penganiayaan, yang membuat Chaplin diakui sebagai seorang tragikomedian yang berhasil (Susanto, 2004:61).

Pada akhir tahun 1940-an dan awal 1950-an Chaplin dikritik karena pandangan politiknya yang kekiri-kirian. Film-filmnya pada masa itu memuat rasa simpati kepada para pasifis, komunis, dan para pendukungnya. Hasilnya, dia meninggalkan AS pada 1952 dan kemudian menjadi warga negara Swiss. Barulah pada tahun 1972 dia kembali sebentar ke AS untuk menerima beberapa penghargaan, antara lain penghargaan Oscar untuk kontribusinya bagi dunia film. Humor tidak hanya sebagai media distorsi kepenatan, kekakuan, kejenuhan, dan kesedihan. Namun di tangan Sebawaee AlMisri dan Charlie Chaplin, humor dan komedi menjadi media untuk melawan kesengsaraan dan penganiayaan.

Tidak berhenti sampai di sini. Perlawanan dengan media humor ala Charlie Chaplin ini terus dilakukan oleh para Sastrawan Arab pada masa Dinasti Fatimiyyah. Salah seorang humoris pada masa ini yang cukup terkenal adalah Ibn Qādūs al-Dimyāti. Ia merupakan kepala 
sekertaris pada masa Dinasti Fatimiyyah periode akhir. Ia melawan kemunafikan dalam ranah politik dengan menggunakan puisi humor. Selain itu ia juga mengungkapkan kekacauan masyarakat sosial (social disorder) dan faham oportunis yang merusak kehidupan pada masa itu dengan menggunakan media humor.

Humor pada masa Dinasti Ayubiyyah mengalami perkembangan yang cukup menarik karena humor pada waktu itu muncul di antara masa perang salib (crusade wars). Qāzi al-Fādil, salah satu menteri dari Shalahuddin, dan Ibnu Sina memperkenalkan jenis humor gaya baru yang disebut dengan 'humor yang mendidik' (educational humor). Jenis humor yang digagas oleh Ibnu Sina dan Qāzi al-Fādil ini tidak banyak memotivasi manusia untuk tertawa namun lebih banyak merangsangnya untuk berfikir. Namun Al-Bahā' Zuhair telah berhasil mengembalikan gaya humor ini kepada bentuk yang lebih kocak, segar, dan penuh lawakan. Salah satu bintang humor dan komedian pada masa ini yang cukup terkenal adalah As'ad bin Mamāti. Ia merupakan sekertaris menteri keamanan dan perpajakan pada masa Shalahuddin alAyubi. Ia telah berhasil menerbitkan sebuah buku yang berjudul al-fashūsh $f i$ hukmi Qraqūsh. Buku tersebut mengkisahkan salah satu pemimpin dari Dinasti Ayubiyyah yang ditempatkan di wilayah Turki yang bernama Qraqūsh. Ibnu Mamāti berhasil melukiskan sosok pemimpin tersebut dengan model humor, jenaka, dan melukiskannya sebagai sosok pemimpin yang idiot dan sembrono dengan menggunakan model gaya lawakan.

Setelah berakhirnya perang salib, humor mengalami era baru pada masa Dinasti Mamluk. Karya sastra yang mengandung humor masih berkutat pada masalah perpolitikan dan para politikus, khususnya Turki. Salah satu korban dari kejenakaan humor pada masa ini adalah Sultan Baibrus, pangeran atau pemimpin muda dari Tartars. Seorang gubernur pada masa Dinasti Mamaluk bernama Tushtumar dijuluki secara humoris dengan himmis akhzar (si buncis yang berwarna hijau), padahal ia adalah seorang gubernur tersohor pada masa itu. Model humor yang terkenal pada masa ini adalah model gaya humor dalam bentuk nyanyian puisi (chanting humorous poetry). Jenis puisi model ini disebut juga dengan istilah alzajjal atau humorist poem of strophic form. Istilah strophic sendiri dalam dunia Sastra sering dikaitkan dengan kata strophe yang berarti 'bait'. Strophe adalah seloka yang terdiri dari tiga atau empat baris (Widodo, 2001:697). Ibnu Sudūn, penulis nuzhatul nafüs wa muzhiq il 'abūs, merupakan salah satu komposer handal dalam strophe pada masa itu. Ia juga banyak menulis karya humor dalam bahasa 'amiyyah.

Humor pada masa ini cukup memasyarakat sampai ke tataran pedagang, tukang daging di pasar dan tukang cukur. Yang menjadi sorotan penting untuk perkembangan gaya baru humor pada masa ini adalah adanya teater masyarakat (public theater) yang dikenal dengan nama Khayāl al-Zill atau shadow play 'pertunjukkan wayang kulit'. Teater humor dengan menggunakan wayang atau boneka pada masa dinasti Mamaluk ini disinyalir sebagai penetrasi budaya Cina pada abad keenam setelah tahun Hijriyyah. Pakar teater humor (komedi) pada masa ini adalah Ibn Daniel. Ia telah berhasil menciptakan tiga drama humor pada masa ini, yaitu: (1) Taif ul Khayal (spektrum imajinasi), (2) Ajeeb wa Gareeb (keanehan dan menakjubkan), (3) Mutayyam (tergilagila). Humor dalam masa ini juga dekat sekali dengan bentuk arajūze, yaitu bentuk puisi yang disusun dengan bachr (meter) rajaz.

Pada Masa Kekaisaran Ottoman, humor politik cukup dominan dan merajai masyarakat pada masa itu. Salah seorang tokoh humornya bernama Yousaf Sharbeeni yang menulis puisi panjang dengan menggunakan bahasa amiyyah dalam bukunya yang berjudul hazzul quhüf (guncangan tengkorak-tengkorak). Senada 
dengan para humoris sebelumnya, Yousaf Sharbeeni konsen mengkritisi kemiskinan masyarakat Arab pada masa itu dengan menggunakan media humor. Kemiskinan yang terjadi pada masa itu sebagai akibat dari buruknya administrasi publik Kekaisaran Ottoman.

Dengan demikian, berlandaskan pada rentetan periode perjalanan humor dalam Sastra Arab di atas, dapat disimpulkan bahwa pada dasarnya masyarakat Arab itu mencintai humor dan komedi. Hal ini membantah pendapat orientalis D.S. Margoliuth dan penulis Mesir Muhammad Khalaf Ahmad yang menyatakan bahwa humor tidak ada dalam karya Sastra Arab kuno. Karya-karya dari Al-Jāhiz, Ibnu Muqaffa, Abu Nawas, dan Abu-Al-Aina menunjukkan tren masyarakat Arab pada humor dan canda tawa.

\section{Penutup}

Setiap manusia pasti pernah tertawa, karena memang tertawa itu memanusiakan manusia. Selain itu, sering kita dengar, bahwa tertawa itu menyehatkan, tertawa itu membuat kita awet muda. Sumber dari tertawa itu salah satunya adalah humor. Humor dalam sastra Arab sebelum Islam berkembang dalam genre puisi yang berbentuk satir - satire. Dalam bahasa Arab sendiri disebut dengan hijā' (هجاء).

Adapun pada masa Islam, satirical style dalam humor justru sering digunakan oleh ayat-ayat al-Qur'an dalam membalas ejekan para hipokrit yang menentang dakwah Nabi Muhammad SAW pada masa itu. Rasulullah sendiri juga terkadang menggunakan model ejekan yang bersifat humor (jesting) ketika berbicara dengan para sahabat. Humor pada kedua masa ini (masa sebelum Islam dan masa Islam) disebut dengan nomadic style. Hal ini dikarenakan humor dalam karya sastra ini masih dekat dengan budaya nomaden atau budaya kabilah gurun pasir yang masih sering berpindah-pindah tempat. Humor dalam karya sastra, khususnya puisi, masih digunakan sebagai media untuk menyerang dan mengejek kabilah atau kelompok yang menjadi lawan. Hal ini sangat berbeda degan humor di masa dinasti Abbasiyah sampai dengan masa Kekaisaran Ottoman yang sudah melebur kepada genre prosa, baik berupa novel, roman, maupun ceritacerita pendek, bahkan drama atau teater masyarakat. Pelopor Prosa Humor dalam Sastra Arab adalah al-Jāhiz dan Ibnu Muqaffa dengan segudang karya tulis perihal humor dan fabel.

Dari pembahasan di atas, memang dapat disimpulkan bahwa pada dasarnya karya Sastra Arab sendiri tidak akan pernah lepas dari unsur-unsur humor dan komedi. Namun perlu diingat, di sisi lain, jika kita mau menengok beberapa bukubuku berbahasa Arab, banyak sekali sebuah pesan agar kita menghindari bercanda (baca: humor). Karena dikhawatirkan humor atau bercanda yang berlebihan akan mengakibatkan hati keras, hilang wibawa, dan menjadi manusia yang tidak pernah serius. Hal tersebut juga diamini oleh beberapa sastrawan modern Arab. Beberapa penulis Arab modern, seperti Muhammad Khalaf Ahmad dan orientalis modern seperti D.S. Margoliouth, menyatakan bahwa "tidak ada" humor dalam Sastra Arab Klasik. Dengan demikian humor sebenarnya menjadi sebuah problematika yang dilematis, ibarat buah simalakama, di satu sisi humor menjadi obat kejenuhan dan media hiburan, bahkan menjadi media untuk merusak (distorsi) kedzhaliman para pemimpin yang arogan, di sisi lain jika terlalu banyak bercanda juga tidak sehat. Lalu bagaimana? Maka "tertawalah sebelum tertawa itu dilarang". Demikian pesan yang selalu disampaikan oleh para komedian Warkop di setiap akhir filmnya dan yakinlah bahwa Khairul-umūri ausāthuha, sebaik-baik masalah itu adalah pertengahannya, tidak berlebihan, namun juga tidak kurang. Wa'Allahu a'lam bishshawab. 


\section{Daftar Pustaka}

Baalbaki, Rohi. 1995. Al-Mawrid Arabic-English Dictionary Edition 7. Beirut: Dar El-Ilm Lilmalayin.

Collin, PH. 1988. Harrap's English Dictionary for Speakers of Arabic. Canada: Kernerman Publishing, Inc.

Hartoko, Dick. dan B. Rahmanto. 1986. Pemandu di Dunia Sastra. Yogyakarta: Penerbit Kanisius.

Al-Jārim, Ali. dan Musthafa Amin. 1999. An-Nachwu AlWādhich Jilid Satu. Mesir: Dārul-Ma'arif.

Lubis, Hasan Hamid. 1994. Glosarium Bahasa dan Sastra. Bandung: Penerbit Angkasa.

Mubeen, Haris. 2008. "Humour and Comedy in Arabic Literature (From the Birth of Islam to Ottoman Period). Al-Hikmat volume 28 , halaman 13-30.
Poerwadarminta, W.J.S. 1976. Kamus Umum Bahasa Indonesia. Jakarta: Penerbit Balai Pustaka.

Rāghib, Nabil. 1996. Mausū'ah al'Ibdā' al-Adabiy. Mesir: AsySyirkah Al-Mishriyyah Al'Ālamiyyah Lin-Nasyri, Longman.

Sugono, Dendy. 2008. Kamus Bahasa Indonesia. Jakarta: Pusat Bahasa Departemen Pendidikan Nasional.

Susanto, Ready. 2004. 100 Tokoh Abad ke20 Paling Berpengaruh: Politisi, Selebritis, Olahragawan, Intelektual, Ulama, Ekonom, Seniman. Bandung: Penerbit Nuansa.

Wargadinata, Wildana. 2008. Sastra Arab dan Lintas Budaya. Malang: UIN Malang Press.

Widodo. 2001. Kamus Ilmiah Populer. Yogyakarta: Absolut.

Zaidan, Abdul Rozak, dkk. 1994. Kamus Istilah Sastra. Jakarta: BalaiPustaka. 